\title{
Economic Analysis of Hybrid Rice in Taluka Golarchi District Baddin Sindh, Pakistan
}

\author{
Qurat Ul Ain Memon ${ }^{1,}$, , Shoaib Ahmed Wagan ${ }^{1}$, Tufail Ahmed Wagan ${ }^{2}$, Irfan Hussain Memon ${ }^{3}$, \\ Zohaib Ahmed Wagan ${ }^{4}$, Hina Memon ${ }^{5}$, Zahoor Ahmed Wagan ${ }^{6}$, Asadullah Jamro 7 , \\ Shakeel Ahmed Wagan ${ }^{8}$, Imran Hussain Memon', Adnan Hussain Memon ${ }^{10}$ \\ ${ }^{1}$ Collage of Economics and Management Anhui Agricultural University, China \\ ${ }^{2}$ Hubei Insect Resources Utilization and Sustainable Pest Management Key Laboratory, College of Plant, Science and Technology, Huazhong \\ Agricultural University, Wuhan, China \\ ${ }^{3}$ Institute of Mathematics and Computer Science, University of Sindh Jamshoro, Jamshoro, Pakistan \\ ${ }^{4}$ Department of Agronomy, Sindh Agriculture University, Tandojm, Pakistan \\ ${ }^{5}$ Department of Agricultural Education, Extension Sindh Agriculture University, Tandojm, Pakistan \\ ${ }^{6}$ Department of Horticulture, Sindh Agriculture University, Tandojm, Pakistan \\ ${ }^{7}$ Department of Rural Sociology, Sindh Agriculture University, Tandojm, Pakistan \\ ${ }^{8}$ Department of Animal Reproduction, Sindh Agriculture University, Tandojm, Pakistan \\ ${ }^{9}$ Library Department, University of Sindh Jamshoro, Jamshoro, Pakistan \\ ${ }^{10}$ Faculty of Arts, University of Sindh Jamshoro, Jamshoro, Pakistan
}

Email address:

anymemon15@yahoo.com (Q. U. A. Memon)

\section{To cite this article:}

Qurat Ul Ain Memon, Shoaib Ahmed Wagan, Tufail Ahmed Wagan, Irfan Hussain Memon, Zohaib Ahmed Wagan, Hina Memon, Zahoor Ahmed Wagan, Asadullah Jamro, Shakeel Ahmed Wagan, Imran Hussain Memon, Adnan Hussain Memon. Economic Analysis of Hybrid Rice in Taluka Golarchi District Baddin Sindh, Pakistan. International Journal of Business and Economics Research.

Vol. 4, No. 6, 2015, pp. 264-269. doi: 10.11648/j.ijber.20150406.11

\begin{abstract}
Rice is second food source after wheat and is an important foreign exchange earning commodity of Pakistan's economy, which gives about $\$ 950$ million annually. Pakistan grows rice including early and late maturing verities, hybrid and conventional rice verities which are consider as high quality rice verities. The study was design to conduct economic analysis of hybrid rice production; major findings of the study were financial gain from hybrid rice. Taluka Golarchi was selected for the present study because it is a hybrid rice cropping zone, primary data on hybrid rice was collected from the farmers through personal interviews with the help of specially designed questionnaire. Result shows that total costs per acre of hybrid rice were 65993.62Rs/Acre which were slightly high due higher hybrid seed prices, slightly higher land management costs. On an average higher yield 78.88monds/acre was obtained from hybrid rice. The gross revenue was received as 85643.96Rs/Acre. Study results further indicate that hybrid rice growers obtained higher gross margin 38199.34Rs/Acre, which gives additional income to poor farmers in study Area. Therefore, gross revenue gained 85643.96Rs/Acre by hybrid rice. High profit was observed in hybrid rice. Most of the farmers focused to grow hybrid rice due to high yield advantage.
\end{abstract}

Keywords: Hybrid Rice, Total Costs, Gross Revenue, Gross Margin, Net Returns

\section{Introduction}

Rice is the staple food for more than half of the world's population. In Asia, more than $80 \%$ of the people live on rice, and their primary food security is entirely dependent on the volume of rice produced in this part of the world. However, rice production increases are now lagging behind population growth. Overall, the total global rice is declining gradually even with the extensive use of the modern varieties such as high yielding and hybrid varieties. (Noonari. S, et al. 2015)

Rice (Oryza sativa L.) is an important cereal food grain crop of the world with an excellent source of calories, in the form of starch, and has added benefits of providing protein with higher nutritional quality than other cereals grains. Different rice research institute i.e. IRRI, have a lot of germ 
plasma collections of rice for the improvement of rice varieties with respect to yield and yield contributing traits. Crop improvement program also depends on the utilization of germ spasm stock that is available in different rice research institutes of the world. Improving and increasing the world's supply will also depend upon the development and improvement of rice varieties with better yield potential, and to adopt various conventional and biotechnological approaches for the development of high yielding varieties that having resistance against biotic and abiotic stresses (Khush, 2005).

Rice is one of the important food crops in the world and ranks second in terms of area and production. It is the staple food for about 50 per cent of the population in Asia, where 90 per cent of the world's rice is grown and consumed. Asia's food security depends largely on the irrigated rice fields, which account for more than 75 per cent of the total rice production (Virk et al., 2004)

It is an important food and cash crop and second staple food source of grain crop of Pakistan after wheat and major source of foreign exchange earnings after cotton.Rice accounts 3.1 percent of the value added in agriculture and 0.7 percent in GDP. During 2013-14 rice is cultivated on an area of 2789 thousand hectares, 20.8 percent higher than last year's area of 2309 thousand hectares. The production stood at 6798 thousand tonnes against the target of 6200 thousand shows a growth of 9.6 percent against the target (Economic Survey of Pakistan, 2013).

In Pakistan's economy rice is second food source after wheat and is an important foreign exchange earning commodity which gives about $\$ 950$ million annually. It is one of the highest water requiring crops, depending on early and late maturing varieties. Coarse grain varieties are early maturing while fine grain varieties are late maturing. Sixty two percent of total rice area is under fine varieties, 27 percent under course grain varieties, and 11 percent under of others varieties. Moreover, about 96 percent of fine varieties are grown in Punjab because there is suitable climate for maintaining the quality and aroma of these varieties. The yield of fine varieties is much lower than the course grain varieties but demand of fine rice is high in national and international markets. Most of the farmers prefer to grow fine varieties despite low yield high production cost and more water requirement. (Khushk et al. 2011).

Sustainable rice production based upon projection of rice production, consumption, demand and supply of fertilisers. Since sustainable yield of crop considerably depends on balanced application of both chemical and organic fertilisers in the field level, the research suggests for increased usage of organic fertilisers. (Basak . J . K et al. 2015)

The term "hybrid rice" refers to the first-generation (F1) offspring of a cross of two genetically diverse parents that yields (performs) better than both parents due to manifestation of a biological phenomenon known as hybrid vigor or heterocyst. Farmers can benefit from hybrids if the F1 (hybrid) seeds are used for commercial cultivation; the grains produced on the commercial hybrid crop are unusable as seed for the next crop because, in the subsequent generations, the yield advantage expressed in the first generation offspring of a hybrid is significantly reduced due to inbreeding depression (asiabiotech). Hybrid rice typically displays heterocyst (or hybrid vigor) such that when it is grown under the same conditions as comparable highyielding inbred rice varieties it can produce up to $30 \%$ more rice. High-yield crops, like hybrid rice, are one of the most important tools for combating world food crises International Rice Research Institute (IRRI).

Hybrid Rice was first commercially cultivated in China in 1976 and its area had been expanded to more than 13 million hectares by 1990 , it proven to have $20 \%$ yield advantage over inbred rice in China (Yuan 2004). During the last decade, Vietnam, India, Philippines, Bangladesh and United States have also started its commercial cultivation. Hybrid rice not only has a distinct yield advantage over Conventional varieties but also is more responsive to fertilizer and can adapt to varying environments (Khushk et al. 2011).

Hybrid rice was successfully developed in China where about 50\% rice area is now under it (Yuan, 1994). Hybrid rice in China produced a yield advantage of 1.0-1.5 t/ha (20$30 \%$ ) over the conventionally bred varieties (Virmani, 1994).

Chinese's income levels have increased, consumers demand for good quality Rice has increased, while Hybrid Rice varieties have not been able to meet this demand. There are evidence that farmers cultivating Hybrid Rice realized 16 percent higher yields than current Conventional varieties in similar agro-climatic zones of Karnataka and Andhra Pradesh. However, in Orissa and Tamil Nadu, India; Hybrid Rice gave lower yield due to pests and disease attack compared to conventional varieties. Hybrid rice research was primarily aimed at reversing the current yield trend in the intensively Rice growing regions. There are evidences to show that farmers cultivating Hybrid Rice realized higher yield gains at 16 percent over current Conventional varieties in similar agro-climatic zones of Karnataka and Andhra Pradesh (Janaiah 2001).

Currently, about 610,000 ha are covered with Hybrid Rice in Vietnam (340,000 ha), India (200,000 ha), Bangladesh (50,000 ha), USA (10,000 ha), Philippines (5,000 ha) and Myanmar (5,000 ha). These have given on average about 20$25 \%(1-1.5 / \mathrm{ha})$ higher yields than the Conventional HYVs, thereby contributing towards higher on-farm productivity. Currently, Hybrid Rice technology is considered a viable option to increase Rice yields globally (Yuan et al 2004).

PARC/NARC has been conducting adaptability trials on rice hybrids in collaboration with Federal Seed Certification and Registration Department since 2005. So far, 367 rice hybrids supplied by different national and multinational seed companies have been tested for adaptability in National Uniform Yield Trial (NUYT). These trials were planted at various locations throughout the country. The crop stand of few hybrids was excellent and out yielded the commercial variety, IR-6. Fifty four rice hybrids have already been recommended by Variety Evaluation Committee (VEC) for 
further approval of National and Provincial Seed Councils for general cultivation. In addition, certain resource conservation technologies (RCTs) are being refined and disseminated through viable public-private partnership. In future, such collaborative activities will continue to strengthen the public-private partnership.

In Pakistan two Hybrid Rice varieties GNY50 and GNY53 have been introduced among the Rice growers in Sindh and Balochistan provinces. These varieties have created great demand among Rice growers and consumers. Hence, government approved these varieties for commercial cultivation. Keeping in view the introduction of hybrid rice in rice growing areas in Sindh and there is confusion among rice growers, traders, development specialists and policy makers about the hybrid rice and they face number of problems in cultivations. Therefore there is further need of study of hydride rice, this study shall be conducted to assess the Economic Analysis of hybrid rice varieties in the rice growing areas in Sindh.

\section{Objectives}

1. To determine production costs, physical productivity and net return of hybrid rice.

2. To identify the issues and suggest the policy measures for sustainable hybrid rice.

\section{Methodology}

The study was conducted by primary data collection from growers of rice from Taluka Golarchi District Badin. The main focus of study was to determinants the affecting rice yield and financial gains from rice activities (hybrid rice). Primary data was collected from sample of 60 hybrid rice growers, farmers was selected by random sampling techniques in Taluka Golarchi District Badin. Selected hybrid rice growers were interviewed by well designed questionnaire to collect the data. To accomplish the objectives mentioned above the specific analytical techniques ware used to analyse the data. The objectives of study was accomplished by the rapid rural survey method togather baseline information on production of hybrid rice crop and by collecting cross section micro level data from the hybrid rice crop growers in Taluka Gorachi District Badin Sindh.

The analytical techniques such farm cost and production analysis based on hybrid rice production were used to found the result. The results of this study were provided total costs and returns of hybrid rice. Total costs consist of expenditure from the profit and loss account (fixed costs and variable costs etc.). For the estimation and calculations, following procedure is adopted to examine the profitability of hybrid rice.

Average $=\Sigma \mathrm{Xi} / \mathrm{n}$

Percentage $=\mathrm{F} / \mathrm{N} \times 100$

$\mathrm{TC}=\mathrm{TFC}+\mathrm{TVC}$

$\mathrm{TR}=\mathrm{TPP} \times \mathrm{P}$

$\mathrm{NR}=\mathrm{TR}-\mathrm{TC}$

$\mathrm{GM}=\mathrm{TR}-\mathrm{VC}$

\author{
$\mathrm{TC}=$ Total Cost \\ $\mathrm{TFC}=$ Total Fixed Cost \\ $\mathrm{TVC}=$ Total Variable Cost \\ $\mathrm{TR}=$ Total Returns \\ $\mathrm{TC}=$ Total Cost \\ $\mathrm{GM}=$ Gross margin \\ $\mathrm{TR}=$ Total return \\ $\mathrm{VC}=$ Variable costs \\ $\mathrm{TPP}=$ Total physical productivity \\ $\mathrm{P}=$ Price
}

\section{Results}

The general objective of study was to find out the yield of hybrid rice crop. Most of the farmers focused to cultivate hybrid rice; they get greater benefits from hybrid rice. Results further discussed as under.

\subsection{Rice Varieties Planted by Sample Farms}

The seed varieties are the most of the important input for crop production, Quality seed is the base to increase the productivity

Table 1. Percent Area under different hybrid rice varieties in study area.

\begin{tabular}{ll}
\hline VarietiesArea & Percentage \\
\hline Guard-53 & 28.22 \\
Pokraj-101 & 33.80 \\
Pride & 5.57 \\
Anmol & 5.27 \\
Mehrani & 6.61 \\
Dhaga & 3.48 \\
Shahnshah-1 & 8.44 \\
Winner & 8.36 \\
\hline
\end{tabular}

Table 1 indicates that About 8 hybrid rice varieties were cultivated by sample farmers in the study area. Area of varieties under cultivation of hybrid rice were $28.22 \%$ of Guard-53, 33.80\% Pokraj-101,5.57\% Pride, 5.27\% Anmol, 6.618\% Mehrani, 3.48\% Dhaga, 8.44\% Shahnshah-1 and $8.36 \%$ Winner. The most popular varieties of hybrid rice were plantedPokraj-101, Guard-53 and Shahnshah-1.

\subsection{Land Management}

Land management is the first task for better crop production. A good land management is necessary for proper and rapid growth of the crop. Normally deep plowings are done half feet below the surface and sub soil. After plowing, land is left for few days to get air and sunlight.

Table 2. Land management practices.

\begin{tabular}{ll}
\hline Management practices & Numbers \\
\hline Deep plough & 1 \\
Disc Harrow & 1 \\
Goble & 2 \\
Cultivator & 2 \\
Leveller/blade & 1 \\
ploughing+Planking & 1 \\
Total & 8 \\
Seed rate Kg/Acre & 5.76 \\
\hline
\end{tabular}


Table 2 shows that majority of the farmers prepared their land with Goble followed by cultivator, rotavator, deep plough leveler and ploughing with planking. For hybrid varieties 2 times plowed their land with cultivator followed by Goble 2 time, Disc Harrow 1 time, Leveler/blade 1 time,ploughing+Planking 1 time and deep plough 1 time.

\subsection{Planting Time}

Planting time plays an important role in the growth and yield of any crop. During the survey it was noted that growers usually plant their crop earlier for getting better market prices. However, it was also noted that sowing early crop is a risk in terms of germination of seed and disease and insect pests attack. The growers usually decide the planting time for rapid and successful growth by monitoring the climatic conditions of the area.

Table 3. Planting time of hybrid rice.

\begin{tabular}{ll}
\hline Month & Number Respondent \\
\hline June & 14 \\
July & 24 \\
August & 22 \\
\hline
\end{tabular}

Table 3 shows that there were 14 respondents planted in month of June, 24were in July and 22 were planted in month of August.

Planting Methods

Rice is usually planted as seedlings and then transplanted in to field. Some growers used direct seed drilling into the soil. Growers usually raised seedlings for 25 to 35 days. During this period the grower take care of the seedlings for their survival.

\subsection{Planting Methods}

Rice is usually planted as seedlings and then transplanted in to field. Some growers used direct seed drilling into the soil. Growers usually raised seedlings for 25 to 35 days. During this period the grower take care of the seedlings for their survival.

Table 4. Planting Methods.

\begin{tabular}{ll}
\hline Sowing Method & Number of respondent \\
\hline Transplanting & 60 \\
Drill sowing & 0 \\
Both & 0 \\
\hline
\end{tabular}

Table 4 shows that most of the farmers prefer to use transplanting method of sowing in study area.

\subsection{Total Fixed Costs}

Total fixed costs are the costs that do not change with the level of production. For example, the cost of owning a building is incurred regardless of whether the building is empty, half full, or overflowing.
Table 5. Total Fixed Costs of Hybrid Rice.

\begin{tabular}{ll}
\hline Total Fixed Costs & (Rs/Acre) \\
\hline Land Rent & 18245 \\
Land tax & 97 \\
Water charge & 207 \\
Total & 18549 \\
\hline
\end{tabular}

Table 5shows that the total fixed cost of hybrid rice was 18549Rs/Acre which includes Land Rent, Land tax, and water charges.

\subsection{Total Variable Costs}

Total variable costs are the costs that change inproportion to changes in volume. These costs relate to the cost incurred for the use of variable inputs. Variable costs includes costs of cultivation, costs of labour, cost on seed (seed price and seed treatment), costs of fertilizers, costs of intercultural practices, costs of irrigations(tube well irrigation also be included),Fungicides costs, Weedicides costs pesticides costs, micro nutrients (zinc, boron etc)rice harvesting cost etc.

Table 6. Total variable costs of Hybrid Rice.

\begin{tabular}{llll}
\hline Costs & Quantity & Price/Unit Total & Rs/Acre \\
\hline Ploughing & 8 & 1508.18 & 12065.44 \\
Seed (Kg) & 5.76 & 1010.38 & 5819.88 \\
Bed making No & 5 & 209.66 & 1048.34 \\
Sowing (Man/day) & 10 & 264.29 & 2517.33 \\
Fertilizers (Bags) & 3 & 2642.91 & 7928.73 \\
Weedicide & 1 & 850.00 & 850.00 \\
Zink, Boron (begs) & 2 & 1882.16 & 3764.12 \\
Irrigations (No.) & 21 & 0.00 & 0.00 \\
Pesticides (No.) & 3 & 838.00 & 2514.00 \\
Harvesting (M/day) & 11 & 308.60 & 3395.57 \\
Threshing Rs/Min & 44 & 79.00 & 3509.57 \\
Packing & 19 & 79.41 & 1477.82 \\
Transportation & 16 & 79.41 & 1273.74 \\
Commission & 2.85 & 79.41 & 640.04 \\
Load/unload & 8 & 79.41 & 640.04 \\
Total variable costs (Rs/Acre) & & & 47444.62 \\
\hline
\end{tabular}

Table 6 shows that the total variable costs for Hybrid rice were $47444.62 \mathrm{Rs} /$ Acre. Cost of hybrid seed was high due to slightly high price.

\subsection{Total Revenue}

Total revenue is the total money received from the sell of output. The total revenue is calculated by taking the pricemultiplied by quantity sold.

$($ Total revenue $=$ price $\mathrm{x}$ quantity $)(\mathrm{Biz} 2002)$.

Table 7. Total physical productivity and total revenue of hybrid rice.

\begin{tabular}{ll}
\hline Hybrid & Rice \\
\hline Yield mds/acre & 78.88 \\
Price Rs/mds & 1085.75 \\
Gross Revenue (Rs/acre) & 5643.96 \\
\hline
\end{tabular}

Table 7 shows thatoverall high yields was obtained $78.88 \mathrm{mds} /$ acre from hybrid rice. As for prices concerned, the hybrid rice growers received price as $1085.75 \mathrm{Rs} / \mathrm{mds}$, and 
the total revenue was obtained as $85643.96 \mathrm{Rs} /$ acre.

\subsection{Gross Margin and Net Return}

Gross margin is the difference between total revenue and total variable costs. Total variable costs are the sum of total labour costs and total factor cost. Net Return is the value that remains after all costs; it is calculated by Gross Revenue subtracted by total costs. (Net Return = Gross Revenue- total costs.)

Table 8. Gross Margin and Net Return of Hybrid Rice.

\begin{tabular}{ll}
\hline Hybrid & Rs/Acre \\
\hline Gross Revenue & 85643.96 \\
Fixed Costs & 18549.00 \\
Variable Cost & 47444.62 \\
Net Return & 19650.34 \\
Gross Margin & 38199.34 \\
Total Cost & 65993.62 \\
\hline
\end{tabular}

Table 8shows that hybrid Rice growers in selected study area were obtained higher gross margin 38199.34Rs/acre, the net return of hybrid rice production was calculated that hybrid rice growers received higher net return which were19650.34 Rs/Acre.

\section{Discussion}

Better crop production depends upon soil structure, climatic condition, quality inputs, better crop management and favorable marketing system. It is, therefore, considered meaningful to have brief discussion of area and production levels of hybrid rice production in Sindh province of Pakistan, which is the rice cropping zone of Pakistan.

Study revealed that overall cost of land management and seed on hybrid rice was high due to more land management practices and high seed rate. The use of fertilizer is much more less in hybrid rice. Overall high yield was obtained $78.88 \mathrm{mds} /$ acre from hybrid rice, and the gross revenue was received as $85643.96 \mathrm{Rs} /$ acre. Study results further indicate that hybrid rice growers obtained higher gross margin 38199.34 Rs/acre. Therefore, income gained per acre 85643.96 rupees by hybrid rice.

Majority of Farmers were focusing to cultivate hybrid rice, because of it gives better yield, result highlighted that the cost of production of hybrid rice $47444.62 \mathrm{Rs}$ /Acre which were little bit high. Major reasons of high cost were higher seed prices, slightly higher land management costs. The study compared with the study of Khushk et al. (2011) on performance of rice hybrid and other varieties shown as under.

Khushk et al. (2011) assess the performance of rice hybrid and other varieties planted in rice growing areas of Sindh and Balochistan during the year 2008-2009. The results revealed that average yield of hybrid rice was $195 \mathrm{mds} / \mathrm{hectare}$, followed by IRRI-6 (151 mds/hectare), B-2000 (91 mds/hectare) and Rosi (94 mds/hectare). This indicates that the yield of hybrid rice was higher by 29 percent than the major variety IRRI-6. However, the growers received low price by Rs. $8 / \mathrm{mds}$ for hybrid rice against IRRI-6 variety. The main reasons for low price were reported as poor grain quality i.e. high percentage of broken rice and variation in the grain size. This study concludes that overall growers earned more profit by cultivation of hybrid seed technology but there are some repercussions of this technology such as, growers have to buy costly seed every year and have to depend on seed companies. Additionally there is a loss of age-old knowledge and tradition of seed production that sustained rice farming from centuries.

\section{Conclusion and Suggestion}

This study was carried out to economic analysis of hybrid rice based on the field survey in the rice cropping zone of Sindh. The information was collected from selected hybrid rice growers. The data was collected through personal interviews. Number of analytical techniques has been used to access cost of production and production analysis of hybrid rice i.e. farm cost analysis, net return analysis; gross margin analysis.

Major findings were production cost of hybrid rice slightly high which was47444.62Rs/Acre due to higher seed prices, slightly higher land management costs in hybrid rice. The result indicates that significant increase in output of hybrid rice production is related to the higher yield potential of hybrid rice was $78.88 \mathrm{mds} /$ Acre.

Present study clearly indicates that hybrid rice farmers were increasing farm yield and farm profit. Hybrid rice production offers farmers an excellent aid in better managing production, gross margin and increase net returns, as well as reduces net return variability from year to year, to the farming operation. Farmers were focusing to increase the hybrid rice area. Hybrid rice production created opportunities for rural employment. However, the analysis shows that hybrids have contributed very minimally to the improvement of paddy yield. Therefore, it is concluded that growing hybrid rice is a better way, through which farmers should be increase the production, gross margin and increase net returns. By increasing hybrid rice production farmers were improve the living intended.

\section{References}

[1] Biz. (2002) The Break-Even Point, Bristol, UK: University of Bristol, Institute for Learning and Researc Technology, (accessed June, 2006) http://www.bized.ac.uk/virtual/vla/theories/break_even.html.

[2] Government of Pakistan, Economic survey of Pakistan2013, http://www.finance.gov.pk.

[3] IRRI. International Rice Research Institute.http://www.irri.org

[4] Janaiah A, M Hossain and M Hussain (2001). Hybrid for tomorrow's food security: can theChinese miracle be replicated in other countries, journal outlook onAgriculture Vol.31, No.1 PP23-33. 
[5] KhushGurdev S 2005. What it will take to Feed 5.0 Billion Rice consumers in 2030. Plant Molecular Biology. 59:1-6.

[6] Khushk A M, M I Lashari and A Memon, 2011. Performance of hybrid and other rice verities in Sindh and Balochistan J. Agric. Res., 49(4).

[7] Pakistan Agricultural Research Council (PARC) National Agricultural Research Centre (NARC) http:// www.parc.gov.pk/.

[8] Pakistan bureau of statistics, Government of Pakistan, http://www.pbs.gov.pk/content/pakistan-statisticalyear-book2013.

[9] Varmani, S. S. 1994. Prospects of hybrid rice in the tropics and subtropics. In: hybrid Rice technology: New development and Future Prospects. (S. S Virmani, Ed.) Intl. Rice REs. Inst. Manila, Philippines. pp. 7-19.

[10] Virk, P. S., Khush, G. S. and Peng, S. (2004) Breeding to Enhance Yield Potential of Rice at IRRI: The IdotypeApproach, IRRI, p. 5-9.

[11] Yuan Longping. 2004. Hybrid rice for food security in the world, FAO rice conference, Rome, Italy. http://www.fao.org/rice2004/en/pdf/longping.pdf.
[12] Yuan Longping. 2004. Hybrid Rice Technology for Food Security in the World The World Food Prize International Symposium.

[13] Yuan, L. P. 1994. Increasing yield potential of rice by exploitation of heterosis. In: Hybrid Rice technology: New development and Future prospects (S. S. Virmani, ed.) Intl. Rice Res. Newsl, Manila, Philippines. pp. 1-6.

[14] Yuan, L. P. 1994. Increasing yield potential of rice by exploitation of heterosis. In: Hybrid Rice technology: New development and Future prospects (S. S. Virmani, ed.) Intl. Rice Res. Newsl, Manila, Philippines. pp. 1-6.

[15] Noonari. S, Ms. Irfana Noor Memon, Asif Ali Jatoi, Muola Bux peerzadio, Abass Ali Chandio, Shoaib Ahmed Wagan, Asif Ahmed Sethar, Ghulam Yasin Kalwar, Mukhtiar Ali Bhatti, Abdul Sami Korejo, Ghulam Mustafa Panhwar, Taimoor Shah (2015) Analysis of Rice Profitability and Marketing Chain: A Case Study of District Sukkur Sindh Pakistan. International Journal of Business and Economics Research 2015; 4(3):133-143.

[16] Basak. J. K, Rashed Al Mahmud Titumir, Khosrul Alam (2015) Future Fertiliser Demand and Role of Organic Fertiliser for Sustainable Rice Production in Bangladesh, Agriculture, Forestry and Fisheries 2015; 4(5): 200-208. 